\title{
Impact of soy consumption on human health: integrative review
}

\section{Impacto do consumo de soja sobre a saúde humana: revisão integrativa}

\author{
Carlos Alberto Nogueira-de-Almeida ${ }^{1 *}$ (D), Ivan Savioli Ferraz² ${ }^{2}$ Fábio da Veiga Ued $^{2}$, \\ Ane Cristina Fayão Almeida², Luiz Antonio Del Ciampo ${ }^{2}$
}

${ }^{1}$ Universidade Federal de São Carlos (UFSCar), Departamento de Medicina, Ribeirão Preto/SP - Brasil

${ }^{2}$ Universidade de São Paulo (USP), Faculdade de Medicina de Ribeirão Preto, Departamento de Puericultura e

Pediatria, Ribeirão Preto/SP - Brasil

*Corresponding Author: Carlos Alberto Nogueira-de-Almeida, Universidade Federal de São Carlos (UFSCar), Departamento de Medicina, Rod. Washington Luíz, km 235 - SP 310, CEP: 13565-905, São Carlos/SP - Brasil, e-mail: dr.nogueira@me.com

Cite as: Nogueira-de-Almeida, C. A., Ferraz, I. S., Ued, F. V., Almeida, A. C. F., \& Del Ciampo, L. A. (2020). Impact of soy consumption on human health: integrative review. Brazilian Journal of Food Technology, 23, e2019129. https://doi.org/10.1590/1981-6723.12919

\begin{abstract}
Soy consumption is a millenary habit of populations of the eastern world and has recently increased in the western world. The risks and benefits of this practice have been extensively studied, with a current fundamental need of integration of available information. The aim of this study was to carry out an integrative review on this topic, in order to consolidate the available information. Based on the main question: "What is the impact of soy consumption on human health?", were reviewed publications classified as original articles and reviews published from 1998 to 2020 in the databases Scopus, PubMed, SciELO, Web of Science, and Cochrane Library. A total of 97 studies were selected. In the present review were described the general impact of soy on human health and its protein quality, the effects of early exposure using soy formulas, and the effects of soy consumption on breast cancer, endometrial and ovarian cancer, prostate cancer, gastrointestinal cancer, cardiovascular disease, glucose metabolism and type 2 diabetes, obesity, reproductive health, menopause, female and male osteoporosis, microbiota, immunity and immunomodulation, thyroid function, attention-deficit hyperactivity disorder, and renal function.
\end{abstract}

Keywords: Soybeans; Genistein; Isoflavone; Phytoestrogens; Health; Cancer; Nutrition.

\section{Resumo}

O consumo de soja é um hábito milenar de populações do mundo oriental e aumentou recentemente no mundo ocidental. Os riscos e benefícios dessa prática têm sido extensivamente estudados, com uma necessidade fundamental atual de integração das informações disponíveis. O objetivo deste estudo foi realizar uma revisão integrativa sobre este tema, a fim de consolidar as informações disponíveis. Com base na principal questão: "Qual o impacto do consumo de soja na saúde humana?", foram revistas publicações classificadas como artigos originais e revisões publicadas de 1998 a 2020 nas bases de dados Scopus, PubMed, SciELO, Web of Science e Cochrane Library. Foram selecionados 97 estudos. Na presente revisão, foram descritos o impacto geral da soja sobre a saúde humana e sua qualidade proteica, os efeitos da exposição precoce com fórmulas de soja e os efeitos do consumo 
de soja no câncer de mama, endometrial e ovariano, câncer de próstata, câncer gastrointestinal, doença cardiovascular, doenças do metabolismo da glicose e diabetes do tipo 2, obesidade, saúde reprodutiva, menopausa, osteoporose feminina e masculina, microbiota, imunidade e imunomodulação, função da tireoide, distúrbio de déficit de atenção e hiperatividade, e função renal.

Palavras-chave: Soja; Genisteína; Isoflavona; Fitoestrógeno; Saúde; Câncer; Nutrição.

\section{Introduction}

Soy and the food products that use it as an ingredient such as oils, salads, tofu, sauces, liquids and supplements, among others, have been consumed for decades in Asian countries. Soybeans contain approximately $40 \%$ proteins, $15 \%$ mono/oligosaccharides, $15 \%$ fibers, and $20 \%$ lipids. They also contain micronutrients such as zinc, copper, potassium, phosphorus, magnesium, B vitamins and vitamin C. Soybean plants are legumes belonging to the same family as that of beans, peas and lentils (Chen et al., 2012).

Despite its plant origin, soy stands out for its protein quality. Soy protein can be extracted by different processing techniques that result in a variety of ingredients such as textured soy protein, soy flour, soy protein concentrate and soy protein isolates, which can be incorporated into various food preparations (Medic et al., 2014).

A recent increase in soy consumption is being observed in the western world due to the protein content and good quality lipids of the plant (Messina, 2016b), in addition to isoflavones, which are phytoestrogens that can act like estrogen and as modulators of estrogen activity (Messina, 2016b). Due to its functional properties, several benefits have been attributed to the consumption of soy (Messina et al., 2017), such a reduction of menopausal symptoms, prevention of cardiovascular and breast disease, prostate cancer, and reduction of osteoporosis. On the other hand, the presence of isoflavones in some foods has raised concerns about undesirable hormonal effects that might target some individuals (Helferich et al., 2008).

In view of the diversity of information about the risks and benefits of soy consumption, the objective of the present study was to provide a synthetic description of the main lines of evidence about the effects of this plant, proposing a review of reviews.

\section{Methodology}

It is an integrative review carried out according to the following steps: 1) elaboration of the leading question, definition of keywords and of inclusion/exclusion criteria of the articles; 2) article selection; 3 ) categorization of the studies; 4) definition of the information to be extracted from the works reviewed; 5) analysis and discussion of the results; 6) synthesis of the knowledge detected in the articles analyzed, and presentation of an integrative review (Mendes et al., 2008).

It was asked the main question: "what are the effects of soy consumption on human health?". The inclusion criteria adopted in the present study were publications classified as reviews (narrative, integrative and systematic reviews, and meta-analyses) based on the investigation of the risks and benefits of soy consumption for human health published between 1998-2020; and full articles with available abstracts and indexed in the following databases: Scopus, PubMed, SciELO, Web of Science, and Cochrane Library. Original articles whose subjects were not considered in review studies were also included in order to complement the discussion of the topic. Editorials, letters to the editor, reflexive studies, case reports and studies that did not consider the topic related to the objective of the present review were excluded.

The database search was conducted in 2020 using the Health Sciences Keywords (DeCS) and the Medical Subject Headings (Mesh). The Boolean operators "and" and "or" and their respective keywords were used: soybeans, soy foods, soybean proteins, isoflavones and health. The search yielded 21,620 studies. 
The results of the search were screened by three qualified investigators based on the titles and abstracts of the articles. After the identification of the relevant studies, the complete publication was retrieved and reviewed by the three professionals to determine the eligibility for final inclusion. A total of 97 studies were selected.

In order to synthesize the knowledge detected in each study the present review was structured according to the following themes: 1) general impact on human health and protein quality of soy; 2) risks of soy consumption to human health; 3 ) effects of early exposure to and of the use of soy formulas; 4) breast cancer; 5) endometrial and ovarian cancer; 6) prostate cancer; 7) gastrointestinal cancer; 8) cell sensitization for radiotherapy; 9) cardiovascular disease; 10) glucose metabolism and type 2 diabetes mellitus; 11) obesity; 12) reproductive health; 13) menopause; 14) female osteoporosis; 15) male osteoporosis; 16) vegetarian diets; 17) microbiota; 18) immunity and immunomodulation; 19) thyroid function; 20) attention-deficit hyperactivity disorder; 21) renal function.

\section{Results and discussion}

\subsection{General impact on health and protein quality of soy}

In 1999 the Food and Drug Administration (FDA) approved the claim for soy in the US which permits the affirmation of its role in the prevention of coronary artery disease, an action then followed by the United Kingdom, South Africa, The Philippines, Indonesia, Korea, and Malaysia (Xiao, 2008). This claim is also permitted in Brazil but with the caveat that health benefits would occur with an intake of at least $25 \mathrm{~g}$ soy per day (Brasil, 2016).

Until recently soy was recognized as a source of protein of inferior quality in view of its deficiency of sulfur amino acids, especially methionine (Pires et al., 2006). However, new methods for the analysis of the amino acid profile of foods such as the protein digestibility corrected amino acid score (PDCAAS) have defined soy as an excellent protein source (Castellanos et al., 2006). Soy is the only plant-based protein of high quality when compared to all other plant proteins (Hughes et al., 2011).

Researchers emphasize the beneficial effects of soy on the health of adults such as improved glycemic metabolism, weight control, improved lipid profile, prevention of neoplasias, and bone remodeling (Cederroth \& Nef, 2009). Some of these effects are clearly due to the isoflavones but others are still being studied since soy contains various ingredients with the potential to act as functional nutrients (Ramdath et al., 2017).

An important review was published in 2017 about the impact of soy consumption on human health with special emphasis on children. In general, the review determined that there was no demonstration of a hormonal effect or of alterations of puberty. In addition, there is evidence that the prevention of breast cancer is more marked when soy consumption starts during childhood (Messina et al., 2017).

\subsection{Health risks of soy consumption}

Some health risks have been mentioned regarding soy consumption, the more common being breast cancer, male feminization, changes in male fertility and in thyroid function (Messina, 2016b). However, safety evaluation studies have not demonstrated relevant risks for human beings (Messina, 2010). In a review study, D'Adamo \& Sahin (2014) observed that most studies have reported data that do not permit to conclude the presence of risk. This aspect is possibly related to the difficulty of extrapolating the results of animal studies to humans and also due to the heterogeneity of the methodologies used.

Another feature of soy that has been frequently discussed is the presence of antinutritional factors since raw soybeans contain trypsin inhibitors (Kunitz protease) which affect growth and basal metabolism in animal models (Armour et al., 1998). In addition, the lecithins present in soy have affinity for glycosylated receptors of epithelial cells of the intestinal mucosa, thus possibly interfering with digestion and absorption 
processes (Silva \& Silva, 2000). However, heat treatment or simple fractionation during processing eliminates the effects of these factors (Friedman \& Brandon, 2001).

Soy allergy has been extensively reviewed by Katz et al. (2014) who detected a prevalence of allergy ranging from zero to $0.5 \%$ for the general population, from $0.4 \%$ to $3.1 \%$ for children referred to a specialized allergy service, and from zero to $12.9 \%$ among children known to be atopic. After the use of soy formulas, the incidence of sensitization was $8.8 \%$. In general, compared to other protein foods, soy is considered to have very low allergenicity levels (Cordle, 2004).

\subsection{Effects of early exposure to soy and the use of soy formulas}

Considered to be phytoestrogens, isoflavones and, more precisely, genistein, have been studied in terms of their hormonal effects on a growing organism. There are also concerns about their possible "endocrine disruption" effect (Bar-El Dadon \& Reifen, 2010), although this aspect has not been adequately explored and only represents a theoretical model. So far, almost all studies have been conducted on animal models (Dinsdale \& Ward, 2010).

Doerge (2011) observed that exposure of rats to genistein throughout their useful life affected the reproductive tissues and the immunological, neuroendocrine and behavioral functions of the animals. Genistein crosses over the placenta of rats and may reach the fetal brain; in these animals, this phenomenon occurs with maternal serum concentrations very similar to those observed in humans who consume soy-based foods and dietary supplements. Toxicological and exposure assessment of rats treated with genistein have demonstrated chronic adverse effects such as an increased incidence of breast fibroadenoma or carcinoma and accelerated reproductive senescence.

A particularly relevant fact is that the diet of some babies exclusively consists of infant soy formula. Vandenplas et al. (Vandenplas et al., 2014, 2011) recognize that serum isoflavone concentrations are higher in babies fed soy formulas than in breastfed babies and babies fed cow's milk. The circulating isoflavone concentrations of these babies overlap those detected in rats fed high genistein doses which exhibited the adverse effects mentioned above. The small margin of exposure between the doses of genistein that produce demonstrable adverse effects in experimental animal models and in formula-fed babies suggests that the possibility of adverse effects should be considered, but studies in humans are necessary. Johnson et al. (Johnson et al., 2008) and Cederroth et al. (2010) have attested to the general safety of soy use but have emphasized that, in view of the scarcity of long-term studies, exposure at the beginning of life should be cautious.

It is relevant to assert that beneficial effects of soy have been reported even with its early use in infant formulas. Donovan et al. (2009) have shown that isoflavones at the habitual doses present in infant formulas can inhibit by $40 \%$ to $60 \%$ the infectivity of the intestinal mucosa by rotavirus, thus possibly reducing the severity of these infections.

In another study, Vandenplas et al. (2014) reassessed the safety of infant formulas based on soy regarding growth, bone health, immunity, cognition and reproductive and endocrine functions. They observed that, despite the high quantities of phytates and aluminum in the soy formulas, the anthropometric patterns of the infants were similar to those of infants fed standard formulas, as also were their concentrations of hemoglobin, serum proteins, zinc and calcium, and the bone mineral content. Although genistein and daidzein concentrations were higher in children fed soy formula, no evidence of a negative effect on reproductive or endocrine function was detected. In addition, the immunological evaluations and the neurocognitive parameters were similar in all groups.

In view of the controversial results presented, some studies (Zeiger et al., 1999) and consensus (Solé et al., 2018) do not recommend the use of formulas based on isolated soy protein for children less than 6 months of age. These formulas present some differences in their composition when compared to formulas based on 
cow's milk (Kemp, 2006). They have more protein (2.45 to $3.1 \mathrm{~g} / 100 \mathrm{kcal})$, are lactose-free, contain phytates (about $1 \%$ to $2 \%$ ) and oligosaccharides that interfere with the absorption of calcium, phosphorus, zinc and iron (the calcium and phosphorus levels, for example, are $20 \%$ higher than cow's milk protein formulas), contain soy glycopeptides that interfere with iodine metabolism, higher aluminum content and the presence of phytoestrogens (isoflavones, genistein and daidzein) (Solé et al., 2018).

The National Toxicology Program of the US Department of Health and Human Services concluded that the possibility of long-term or discrete adverse events on human development or reproduction cannot be ruled out. Although events of this nature have not been described after more than 40 years of using soy proteinbased formulas in the United States, this subject has never been properly studied (McCarver et al., 2011).

\subsection{Breast cancer}

One of the topics most extensively studied regarding the effects of soy on human health is its relationship with breast cancer (Mourouti \& Panagiotakos, 2013). This is due to the main bioactive component of soy, isoflavone, which is considered a phytohormone that acts both to present estrogenic effect and to inhibit this activity (Franke et al., 2014; Messina, 2016a, 2016b). This is relevant if considered the role of estrogen in the development, progression and treatment of some breast cancers.

Several investigators have observed that soy has an anti-cancer effect and that isoflavone has antiestrogen properties, thus having a protective effect against estrogen-sensitive cancers (Douglas et al., 2013; Messina $\&$ Wood, 2008). The fact that this protective effect seems to be always more evident among Asian women has not been explained, but it is speculated that this may be due to factors such as the microbiota, an early beginning of soy consumption, a high intake, and its use in less processed foods (Kim, 2008; Mourouti \& Panagiotakos, 2013; Nagata, 2010; Tansaz \& Boccaccini, 2016; Valladares et al., 2012; Xiao, 2008). Observational studies have demonstrated that, among Asian women, high soy consumption reduces by about $30 \%$ the risk of developing breast cancer, with more consistent results when consumption starts in childhood and adolescence (38). Nagata (Nagata, 2010) considers that protection against breast cancer may require women to have a similar soy intake to Asian diets. Other factors in addition to the amount consumed seem to modify the association between soy isoflavone intake and breast cancer risk, among them the form and source, time of exposure, status of estrogen receptors, and production and hormonal profile of the persons (Nagata et al., 2014).

Although, theoretically, the estrogenic effect of isoflavone represents a risk for estrogen-sensitive neoplasias, this aspect has not been confirmed. Studies have demonstrated that isoflavone consumption does not change the markers of cancer risk such as density (assessed by mammography) and cell proliferation. According to Messina (2016a), studies involving 11,000 American and Chinese women have shown that soy consumption after a diagnosis of breast cancer reduces recurrence and prolongs survival.

In $2008 \mathrm{Wu}$ et al. (2008) showed a statistically significant dose-dependent association between the intake of soy-based foods and the reduction of the risk of breast cancer among Asian women. There was a reduction of risk of about $16 \%$ for each $10 \mathrm{mg}$ increase in isoflavone intake per day, and intake during adolescence had a stronger effect on risk than intake during adulthood. Finally, there was no conclusion about whether habitual soy intake or short-term soy supplementation influences the levels of circulating hormones or the mammographic density.

In a review article, Hilakivi-Clarke et al. (2010) observed that women who consume moderate quantities of soy during life have a lower risk for breast cancer than women who do not, although this protective effect seems to originate with soy intake early in life. The authors also observed that moderate consumption of a diet containing genistein did not increase the risk of breast cancer recurrence in western women and, finally, Asian survivors of breast cancer had a better prognosis of the disease when they continued to consume soyrich diets. 
Cumulative exposure to high quantities of estrogen is a known risk factor for breast cancer, with early puberty, late menopause and hormone replacement therapy being part of this situation. Valladares et al. (2012) observed that girls who consumed large amounts of isoflavones tended to start puberty at a later age.

Dong \& Qin (2011) published a meta-analysis which showed that soy isoflavone consumption was inversely associated with the risk of occurrence of breast cancer although this protective effect of soy was observed only in studies on Asian populations. Soy isoflavone consumption was also inversely associated with the risk of breast cancer recurrence. Stratified analyses have suggested that menopausal status may have an important modifying effect on these associations and were unable to identify a dose-response relationship.

In a meta-analysis study Chen et al. (2014) observed that soy isoflavone intake may reduce the risk of breast cancer among pre- and postmenopausal women in Asian countries. However, in western pre or postmenopausal women there was no evidence suggesting an association between soy isoflavone intake and breast cancer.

In another meta-analysis study Magee \& Rowland (2012) observed that, when soy is used in quantities similar to those consumed by Asian women, there is no increase in the risk for breast cancer, with some studies actually reporting a reduced risk. In addition, they reported that soy does not interfere with the action of tamoxifen or anastrozole, the drugs used for treatment. The studies analyzed also permitted the conclusion that women with polymorphisms that increase the risk of breast cancer may benefit from the consumption of high doses of isoflavones.

Nagata et al. (2014) observed that, in general, soy consumption reduced the risk of breast cancer in Japanese women and that no reviewed study reported an increased risk with this consumption.

In a review of cohort studies Eakin et al. (2015) concluded that diets with low soy or isoflavone concentrations were not associated with any risk of the incidence of breast cancer compared to diets containing large quantities. They also observed that, among women with the disease, soy-rich diets are associated with a $25 \%$ reduction in the risk of recurrence and a $15 \%$ reduction in mortality.

According to Varinska et al. (2015) isoflavones can act by blocking various stages of carcinogenesis. Genistein inhibits enzymes such as tyrosine kinase, DNA topoisomerase II, 5-alpha-reductase, galectin, histidine-protein kinase and cyclin-dependent kinases, all of them involved in cell replication. In addition, genistein has a potent inhibitory effect on angiogenesis, which is considered to be one of the fundamental elements for tumor growth, invasive capacity and metastatic potential.

\subsection{Endometrial and ovarian cancer}

In a meta-analysis Myung et al. (2009) observed an evident protective effect of soy against the development of endometrial and ovarian cancer. Zhang et al. (2015) reviewed case-control and cohort studies jointly and observed that soy consumption was inversely related to the risk of endometrial cancer. This protective effect continued to be present even when the analysis was carried out on subgroups such as "foods based on non-fermented soy", "postmenopausal women", "Asian origin" and "non-Asian origin".

\subsection{Prostate cancer}

According to Jian (2009) one of the factors that explains the lower incidence of prostate cancer among Asian men is the prevalent consumption of fresh vegetables, in particular, soy. In a review study of 2014, van Die et al. (2014) detected several articles with methodological limitations that did not observe a relation between soy or isoflavone consumption and laboratory markers (prostate-specific antigen, sex hormonebinding protein - SHBG -, testosterone, free testosterone, estradiol, and dihydrotestosterone) in patients with prostate cancer. 
However, two studies reported a significant reduction of cancer diagnosis after the administration of soy and/or isoflavone among men at high risk of developing the disease, with additional observation of the high safety of its use. Applegate et al. (2018) and Sugiyama et al. (2013) reported that soy and isoflavone (genistein and daidzein) consumption is associated with a reduced risk of prostate cancer. Mahmoud et al. (2014) reviewed the mechanisms of this protection and observed that isoflavone can regulate the genes that control the cell cycle and apoptosis. In addition, they described other effects at the molecular level such as antioxidant defense, DNA repair, inhibition of angiogenesis and metastasis, potentiating of chemotherapeutic and radiotherapeutic agents, and estrogen antagonism.

\subsection{Gastrointestinal cancer}

In a meta-analysis study Yu et al. (2016) observed that isoflavone leads to the reduction of the risk of developing colorectal cancer. The effect was more significant with the consumption of soy-based foods rather than isoflavone alone among Asian people.

Other properties of isoflavones not related to the action of a phytohormone (e.g. an antioxidant action) are believed to also have a protective effect against other types of cancer. In a review study conducted on 633,476 participants and 13,639 patients with gastrointestinal cancer Tse et al. (Tse \& Eslick, 2016) observed a discrete overall reduction of risk with soy consumption, more relevant for colon and colorectal cancer. However, when the analysis was carried out in relation to the intake of isoflavone, a significant overall reduction of risk to develop cancer of the digestive tract was observed, particularly regarding colorectal cancer.

\subsection{Cell sensitization for radiotherapy}

Hillman \& Singh-Gupta (2011) pointed out that isoflavone, by inhibiting transcription factors of genes essential for tumor proliferation, invasion and neovascularization and improving the results of traditional therapies, can be considered as a supplement in the treatment of women affected by neoplasias in treatment. The intake of soy isoflavones can be an effective complementary therapy by inhibiting the survival signaling pathways of various cancerogenous cells and of angiogenesis through the altered activation of APE1/Ref-1, $\mathrm{NF}-\mathrm{\kappa B}$ and HIF-1 $\alpha$, rendering the cells more sensitive to radiotherapy.

\subsection{Cardiovascular disease}

In view of its numerous components (isoflavones, saponins, protein substances, lecithin and flavonoids), soy has been extensively studied in terms of its effects on the cardiovascular system (Imai, 2015). The mortality rates due to cardiovascular disease are lower in Asian countries than in western countries, a characteristic believed to be linked to the consumption of soy as a basic food for the population (GilIzquierdo et al., 2012).

Anderson \& Bush (2011) assessed the effects of soy on lipoproteins by analyzing studies reporting a total daily soy consumption of up to $65 \mathrm{~g} /$ day and observed that this consumption reduced LDL-cholesterol by $4.2 \%$ to $5.5 \%$, increased HDL-cholesterol by $3.2 \%$ and reduced triglycerides by $10.7 \%$.

Dong et al. (2011) analyzed studies on the effect of isoflavone on the plasma concentrations of C-reactive protein and concluded that, after menopause, women may benefit from frequent soy consumption, especially those with the presence of high levels of this risk marker.

Gil-Izquierdo et al. (2012) emphasized that habitual soy consumption reduced LDL concentrations in hypercholesterolemic patients and also observed that the effect of restoring endothelial function in patients with mild or moderate endothelial dysfunction was more marked when isoflavone was used as a diet complement. 
Liu et al. (2012) assessed the effects of isoflavone on blood pressure and detected a reduction of $2.5 \mathrm{mmHg}$ in systolic pressure and of $1.5 \mathrm{mmHg}$ in diastolic pressure in the group receiving isoflavone compared to control, that shows an even more evident result among individuals with previous hypertension.

Beavers et al. (2012) reviewed the effects of exposure to soy products containing isoflavones on endothelial function measured by flow-mediated vasodilatation. The effect observed was $1.98 \%$ increase with isoflavone alone and $0.72 \%$ increase for products containing isoflavone; thus, the authors concluded that isoflavone intake can improve endothelial function modestly.

Yan et al. (2017) detected a negative association between soy consumption and cardiovascular events in general, with the most significant effect being observed among Asians. When cardiovascular events were studied separately, significant soy protection against coronary disease and cerebrovascular accidents was observed.

A recent study (Ma et al., 2020) that evaluated the results of three prospective cohort studies in the United States, found that increased consumption of isoflavones was associated with a moderately lower risk of developing coronary heart disease. In a study on the effects of non-protein components of soy on cardiovascular health Ramdath et al. (2017) observed that isoflavones and their metabolites can help control blood pressure, blood glucose, obesity, and inflammation.

A large recent prospective study (Talaei et al., 2014) failed to find that soy intake was protective against cardiovascular disease. Despite this, the hypocholesterolemic effect of soy is well-documented and this has led to the regulatory approval of a health claim relating soy protein to a reduced risk of cardiovascular disease (Health Canada, 2015).

\subsection{Glucose metabolism and type 2 diabetes mellitus}

Zhang et al. (2013) conducted a systematic review in order to assess the effect of isoflavone supplementation on glucose metabolism in non-Asian postmenopausal women and detected a significant reduction of blood glucose and insulinemia in the supplemented groups, especially with long-term use.

In a meta-analysis study Li et al. (2018) concluded that the consumption of soy products or soy constituents (soy protein and isoflavone) may be associated with a reduced risk of type 2 diabetes mellitus.

Azadbakht et al. (2008) observed a significant reduction of fasting blood glucose concentrations in individuals with type 2 diabetes who had been consuming soy protein for 4 years compared to control (animal protein).

\subsection{Obesity}

According to Ørgaard \& Jensen (2008) in vitro studies relating soy consumption to obesity suggest that isoflavones may have inhibitory effects on the increase of adipose tissue in vivo. Experiments with rodents and humans have demonstrated that some of these beneficial effects may indeed occur in vivo. However, especially in humans, the actions of soy isoflavones seem to depend on a complex interaction among several factors, such as the presence of soy protein and specific intestinal bacteria.

In a review study Zhang et al. (2013) detected a significant reduction of body weight in non-Asian postmenopausal women with isoflavone supplementation, especially after short-term, low dose $(<100 \mathrm{mg})$ use. With low doses the effect was more evident among normal weight than obese women.

In another meta-analysis Akhlaghi et al. (2017) observed that soy and isoflavone intake was poorly effective on weight reduction in the general population. A small, but significant, increase in body weight was detected in some subgroups under study: obese individuals, an intake of more than $40 \mathrm{~g} / \mathrm{day}$, and when soy intake was compared to meat or to serum protein. However, a reduction of the abdominal circumference was observed in older individuals, in women of any age and when consumption exceeded $40 \mathrm{~g} /$ day. When 
isoflavone was considered separately, a reduction of body mass index was observed when the product was consumed at doses of less than $100 \mathrm{mg} /$ day over a period of 2 to 6 months.

\subsection{Reproductive health}

The effects of phytohormones on women should be carefully assessed since these substances may impact health in various manners. Huber \& Genazzani (2016) observed that soy and isoflavone consumption reduced the serum concentrations of luteinizing hormone (LH) and of follicle stimulating hormone (FSH) by about $20 \%$, prolonging the duration of the menstrual cycle by 1.05 day. No effect was observed on postmenopausal women with only a mild tendency to an increase in estradiol.

Cederroth et al. (2010, 2012; Cederroth \& Nef, 2009) only detected very minor harmful effects of soy consumption on human and animal reproductive health. That was the case for the few studies that assessed the effect of soy formulas in childhood on later sexual development and reproductive health of adults. There is extensive evidence that compared to humans; animals are affected by soy consumption or by exposure to isoflavone. In studies usually involving rodents it has been well accepted that female fertility is interrupted by intrauterine or neonatal exposure to isoflavones.

Regarding male reproductive health studies also conducted on animal models have pointed out that the consumption of soy or phytoestrogens results in change in androgen, LH and FSH levels (Chavarro et al., 2008).

Since isoflavones are structurally and functionally similar to estrogens there is a justified concern about their feminizing effects on men who consume soy. In a meta-analysis study Hamilton-Reeves et al. (2010) did not detect any effect of soy consumption or of isoflavones on the plasma concentrations of free androgens, SHBG, or free and total testosterone in men.

\subsection{Menopause}

The first years after menopause are characterized by several unpleasant symptoms with most women reporting vasomotor symptoms such hot flashes and nocturnal sudoresis. Menopausal women also experience tiredness, vaginal dryness, body pain and pain of psychological origin such as irritability, depression, anxiety, reduced libido and insomnia. Many of these disturbances are attributed to the fall in estrogen production and for this reason hormone replacement therapy (HRT) has been extensively used as a treatment strategy for many years.

Data from the Women's Health Initiative Study (Rossouw et al., 2002) have shown an increased risk of breast cancer and of cardiovascular complications due to this practice, so that HRT is now being abandoned. Naturally because of its role as a phytoestrogen, isoflavone started to be considered as a natural alternative for affected women (Levis \& Griebeler, 2010). Kurzer (2008) reported that supplementation with at least 15 grams/day of isoflavone can reduce hot flashes by $34 \%$, and the higher the effect, the higher the incidence of these flashes throughout the day.

Bolaños et al. (2010) conducted a meta-analysis that revealed a reduced number of episodes/symptoms of vasomotor origin (hot flashes) in postmenopausal women who consumed soy or its derivatives (soy as a dietary supplement, soy extract or isoflavone concentrate). However, the authors affirmed that these results should be interpreted with caution in view of the high heterogeneity detected in the studies.

The aging process may involve some degree of decline of cognitive faculties and various strategies including nutritional ones. Therefore, alternatives have been sought in order to minimize this tendency. Cheng et al. (2015) conducted a meta-analysis involving 1,024 women who had already gone through menopause and had received isoflavone supplementation for 6 to 30 months. They observed an improvement of cognitive tests and visual memory, more marked when supplementation was started early. 


\subsection{Female osteoporosis}

Osteoporosis and its relationship with soy have been studied but some gaps still persist (Poulsen \& Kruger, 2008). However, a lower incidence of the condition has been recognized in groups that consume more isoflavones (Zhang et al., 2008). According to Zhang et al. (2008) genistein can stimulate the osteoblastic function, this being the probable mechanism of action of this phytoestrogen in the maintenance of bone mass. Atmaca et al. (2008) reported that isoflavone improves bone mineral density and markers of bone remodeling and also improves bone rigidity in women after menopause.

Kubota \& Shimizu (2009) have pointed out that soy and various of its subproducts such as natto (traditional Japanese food made from fermented soy), tofu, miso and soy sauce have been consumed for a long time in Japan. They also emphasized that soy is a rich source of plant proteins, containing a relatively high quantity of calcium, in addition to being an important source of isoflavones.

Fermented soy products contain vitamin $\mathrm{K}$ which is involved in the activation of osteocalcin. For this reason some authors believe it would be beneficial to consume adequate daily doses of soy and its subproduct for bone health and the prevention of osteoporosis (Kubota \& Shimizu, 2009).

In a meta-analysis study Ricci et al. (2010) did not observe benefits of isoflavone consumption regarding the loss of bone mass in postmenopausal women or women of an age close to menopause compared to women who did not consume this soy component. However, a single study reported that genistein intake produced favorable results regarding bone mass loss in these women.

In another systematic review Taku etal. (2010) observed that isoflavone supplementation of postmenopausal women induced an increase in serum concentrations of alkaline phosphatase and osteocalcin of $8 \%$ and $10.3 \%$, respectively, compared to non-supplemented women, both of these being laboratory markers of bone neoformation. A decrease of $18 \%$ in urinary excretion of deoxypyridinoline - a marker of bone resorption - was observed. In the same review, the authors observed that soy isoflavones supplementation caused a moderate but significant improvement in the bone mineral density (BMD) of the lumbar spine but had no effect on the hip, femur or trochanter of postmenopausal women. The authors also state that the intake of soy isoflavones for six months seems to be sufficient to exert a beneficial effect on lumbar spine BMD.

In a systematic review of the role of the use of soy isoflavones in the prevention of osteoporosis, Wei et al. (Wei et al., 2012) observed a 54\% increase in BMD and a 23\% reduction of bone resorption, with the most marked effect being detected in postmenopausal women and with doses higher than $75 \mathrm{mg} /$ day for periods of 1 month to 2 years.

\subsection{Male osteoporosis}

Chin \& Ima-Nirwana (2013) reviewed studies conducted on soy consumption and male osteoporosis. Although they observed evidence of a protective effect in animal models and in tissue culture, the few studies on humans did not demonstrate prevention or improvement of osteoporosis in men.

\subsection{Vegetarian diets}

The current choice of vegetarian diets has greatly increased worldwide, with the exclusion of meat, an important source of proteins of high biological value. Within this context, soy has been used as a vegetable alternative to meat because of its high protein content and culinary versatility, leading to a relevant discussion about the safety of its consumption.

Messina \& Messina (2010) observed that soy products can play a beneficial role in vegetarian diets, with the exception of allergic individuals, being the risks of adverse effects not supported by clinical or 
epidemiological studies. Based on epidemiological studies and clinical trials, the optimum soy intake is two to four portions a day for adults.

Rizzo \& Baroni (2018) reported that, in addition to being safe, the use of soy has health benefits. However, they alerted to the fact that many vegetarians consume highly processed soy foods so that, although safety is maintained, some benefits may be lost.

\subsection{Microbiota}

Huang et al. (2016) studied the effects of soy on the human microbiota and observed that, despite the wide variability of the results obtained in different studies, the findings seem to be consistent. An increased number of bifidobacteria and lactobacilli (generally considered to be beneficial) has been observed in both humans and animal models, in addition to a favorable modification of the relationship between Firmicutes and Bacteroidetes.

\subsection{Immunity and immunomodulation}

Soy and its derivatives have been studied due to the immunomodulatory potential of some of its components such as isoflavones, saponins and antocyanins, which act by suppressing certain metabolic pathways (Tezuka \& Imai, 2015).

Genistein suppresses the immune antigen-specific response in vivo and the lymphocyte proliferation response in vitro, but increases the response mediated by cytotoxic $\mathrm{T}$ and $\mathrm{NK}$ cells as well as the production of cytokine from $T$ cells. It should be highlighted that genistein has been used for the treatment of diseases in animal models, with the observation of inhibition of allergic inflammatory responses (Sakai \& Kogiso, 2008).

\subsection{Thyroid function}

Concern about the antithyroid effects of soy is mainly based on experimental research on animals. Indeed, there have been cases of goiter among babies fed soy formula before these products were fortified with iodine (Mezzomo \& Nadal, 2016).

Soy foods and isoflavones are known to have no adverse effect on thyroid function in euthyroid men or women. Precautions should be taken by men with hypothyroidism under treatment since soy protein seems to interfere with levothyroxine absorption. Furthermore, there is a theoretical concern about the possibility to soy causing a worsening of thyroid function in patients with hypothyroidism due to the potential competition for iodine between isoflavones and tyrosine. However, isoflavone iodination is known to be nonsignificant and clinically irrelevant (Messina, 2016b).

\subsection{Attention-deficit hyperactivity disorder}

Crinella (2012) published a study in which it was evaluated the presence of manganese in soy formulas, an element that, according to the authors, is present in large amounts in these products. High manganese concentration was detected in the hair of children with attention-deficit hyperactivity disorder (ADHD). The author pointed out that, considering the multiple determinants of ADHD, it is highly unlikely that the decision to feed a soy formula to the baby would lead to ADHD, by itself (Sakai \& Kogiso, 2008).

Experimental studies have shown that exposure to manganese may also damage the dopaminergic networks of the brain, while other neurotransmitter systems are also affected (Crinella, 2012).

It is also known that exposure to manganese may have adverse effects on the expression of the genes involved in various brain processes, with long-term consequences for neurological development. Manganese homeostasis is not present at birth in human newborns, but it develops slowly over the first months of life. 
Thus, human babies are vulnerable to the absorption of excess manganese, as detected in soy-based baby formulas (Crinella, 2012).

Literature data suggest that choosing not to breastfeed a baby is probably associated with a higher risk for ADHD, but it was not possible to demonstrate that the use of soy formula instead of breast milk would involve a greater risk (Crinella, 2012).

\subsection{Renal function}

As a more alkaline alternative than animal protein sources, soy protein has been associated with beneficial factors for renal health (Anderson, 2008). Also, benefits have been reported regarding antioxidants serum levels and systemic inflammation in patients with early and late chronic kidney disease (Tomayko et al., 2015).

Another advantage is in relation to phosphorus, present in soy protein in the form of phytate, which is less bioavailable than animal protein phosphorus, with a consequent status as a potential alkalinizing agent. Thus, soy consumption can also reduce serum phosphorus, preventing the cardiovascular consequences of high concentrations of this trace element in patients with chronic renal disease since phosphorus homeostasis depends on renal function (Moe et al., 2011; Noori et al., 2010).

A reduction of protein intake preserves renal function in persons with early diabetic renal disease, and the replacement of animal protein with soy protein results in lower glomerular hypertension and reduced urine albumin excretion. Specific peptides, amino acids and isoflavones are the soy components that may be responsible for these benefits (Anderson, 2008).

\section{Final considerations}

The beneficial effects of soy consumption regarding various types of cancer, bone mineralization, improved menopausal symptoms and the prevention of cardiovascular diseases have been well documented. Almost all investigations of the risks of soy use have been conducted on animal models with no extrapolation of the results to human beings. The recent position of the European Food Safety Authority (Additives \& Food, 2015) is that isoflavone has no adverse effects on the breast, thyroid or uterus of postmenopausal women.

Many studies assessing safety have been published without demonstrating relevant risks to human beings. Another aspect frequently discussed regarding soy is the presence of antinutritional factors. However, heat treatment or simple fractionation during processing eliminates the effects of these factors.

Finally, there is the possibility of allergy to soy, a phenomenon that may occur with many other foods, especially those containing protein. In general, compared to other protein foods, soy is considered to have low allergenic levels. Regarding early consumption, modern soy formulas are safe options for baby feeding, with patterns of growth, bone health and metabolic, reproductive, endocrine, immunological and neurological functions similar to those observed in children receiving conventional formulas.

\section{References}

Additives, E. P. F., \& Food, N. S. (2015). Risk assessment for peri-and post-menopausal women taking food supplements containing isolated isoflavones. EFSA Journal, 13(10), 4246. http://dx.doi.org/10.2903/j.efsa.2015.4246

Akhlaghi, M., Zare, M., \& Nouripour, F. (2017). Effect of soy and soy isoflavones on obesity-related anthropometric measures: a systematic review and meta-analysis of randomized controlled clinical trials. Advances in Nutrition, 8(5), 705-717. PMid:28916571. http://dx.doi.org/10.3945/an.117.015370

Anderson, J. W. (2008). Beneficial effects of soy protein consumption for renal function. Asia Pacific Journal of Clinical Nutrition, 17(Suppl. 1), 324-328. PMid:18296369.

Anderson, J. W., \& Bush, H. M. (2011). Soy protein effects on serum lipoproteins: a quality assessment and meta-analysis of randomized, controlled studies. Journal of the American College of Nutrition, 30(2), 79-91. PMid:21730216.

http://dx.doi.org/10.1080/07315724.2011.10719947 
Applegate, C. C., Rowles 3rd, J. L., Ranard, K. M., Jeon, S., \& Erdman, J. W. (2018). Soy consumption and the risk of prostate cancer: an updated systematic review and meta-analysis. Nutrients, 10(1), 40. PMid:29300347.

http://dx.doi.org/10.3390/nu10010040

Armour, J. C., Chanaka Perera, R. L., Buchan, W. C., \& Grant, G. (1998). Protease inhibitors and lectins in soya beans and effects of aqueous heat-treatment. Journal of the Science of Food and Agriculture, 78(2), 225-231. http://dx.doi.org/10.1002/(SICl)1097-0010(199810)78:2<225::AID-JSFA109>3.0.CO;2-1.

Atmaca, A., Kleerekoper, M., Bayraktar, M., \& Kucuk, O. (2008). Soy isoflavones in the management of postmenopausal osteoporosis. Menopause (New York, N.Y.), 15(4 Pt 1), 748-757. PMid:18277912.

http://dx.doi.org/10.1097/gme.0b013e31815c1e7f

Azadbakht, L., Atabak, S., \& Esmaillzadeh, A. (2008). Soy protein intake, cardiorenal indices, and C-reactive protein in type 2 diabetes with nephropathy: a longitudinal randomized clinical trial. Diabetes Care, 31(4), 648-654. PMid:18184902. http://dx.doi.org/10.2337/dc07-2065

Bar-El Dadon, S., \& Reifen, R. (2010). Soy as an endocrine disruptor: cause for caution? Journal of Pediatric Endocrinology \& Metabolism, 23(9), 855-861. PMid:21175082. http://dx.doi.org/10.1515/jpem.2010.138

Beavers, D. P., Beavers, K. M., Miller, M., Stamey, J., \& Messina, M. J. (2012). Exposure to isoflavone-containing soy products and endothelial function: a Bayesian meta-analysis of randomized controlled trials. Nutrition, Metabolism, and Cardiovascular Diseases, 22(3), 182-191. PMid:20709515. http://dx.doi.org/10.1016/j.numecd.2010.05.007

Bolaños, R., Del Castillo, A., \& Francia, J. (2010). Soy isoflavones versus placebo in the treatment of climacteric vasomotor symptoms: systematic review and meta-analysis. Menopause (New York, N.Y.), 17(3), 660-666. PMid:20464785. http://dx.doi.org/10.1097/gme.0b013e3181cb4fb5

Brasil. Agência Nacional de Vigilância Sanitária - ANVISA. (2016). Alimentos com alegacoes de propriedades funcionais e ou de saúde. Brasília: ANVISA.

Castellanos, V. H., Litchford, M. D., \& Campbell, W. W. (2006). Modular protein supplements and their application to long-term care. Nutrition in Clinical Practice, 21(5), 485-504. PMid:16998147. http://dx.doi.org/10.1177/0115426506021005485

Cederroth, C. R., \& Nef, S. (2009). Soy, phytoestrogens and metabolism: a review. Molecular and Cellular Endocrinology, 304(1-2), 30-42. PMid:19433245. http://dx.doi.org/10.1016/j.mce.2009.02.027

Cederroth, C. R., Auger, J., Zimmermann, C., Eustache, F., \& Nef, S. (2010). Soy, phyto-oestrogens and male reproductive function: a review. International Journal of Andrology, 33(2), 304-316. PMid:19919579. http://dx.doi.org/10.1111/j.13652605.2009.01011.x

Cederroth, C. R., Zimmermann, C., \& Nef, S. (2012). Soy, phytoestrogens and their impact on reproductive health. Molecular and Cellular Endocrinology, 355(2), 192-200. PMid:22210487. http://dx.doi.org/10.1016/j.mce.2011.05.049

Chavarro, J. E., Toth, T. L., Sadio, S. M., \& Hauser, R. (2008). Soy food and isoflavone intake in relation to semen quality parameters among men from an infertility clinic. Human Reproduction (Oxford, England), 23(11), 2584-2590. PMid:18650557. http://dx.doi.org/10.1093/humrep/den243

Chen, K. I., Erh, M. H., Su, N. W., Liu, W. H., Chou, C. C., \& Cheng, K. C. (2012). Soyfoods and soybean products: from traditional use to modern applications. Applied Microbiology and Biotechnology, 96(1), 9-22. PMid:22872103. http://dx.doi.org/10.1007/s00253-012-4330-7

Chen, M., Rao, Y., Zheng, Y., Wei, S., Li, Y., Guo, T., \& Yin, P. (2014). Association between soy isoflavone intake and breast cancer risk for pre- and post-menopausal women: a meta-analysis of epidemiological studies. PLoS One, 9(2), e89288. PMid:24586662. http://dx.doi.org/10.1371/journal.pone.0089288

Cheng, P. F., Chen, J. J., Zhou, X. Y., Ren, Y. F., Huang, W., Zhou, J. J., \& Xie, P. (2015). Do soy isoflavones improve cognitive function in postmenopausal women? A meta-analysis. Menopause (New York, N.Y.), 22(2), 198-206. PMid:25003621. http://dx.doi.org/10.1097/GME.0000000000000290

Chin, K. Y., \& Ima-Nirwana, S. (2013). Can soy prevent male osteoporosis? A review of the current evidence. Current Drug Targets, 14(14), 1632-1641. PMid:24354587. http://dx.doi.org/10.2174/1389450114666131216222612

Cordle, C. T. (2004). Soy protein allergy: incidence and relative severity. The Journal of Nutrition, 134(5), 1213S-1219S. PMid:15113974. http://dx.doi.org/10.1093/jn/134.5.1213S

Crinella, F. M. (2012). Does soy-based infant formula cause ADHD? Update and public policy considerations. Expert Review of Neurotherapeutics, 12(4), 395-407. PMid:22449212. http://dx.doi.org/10.1586/ern.12.2

D'Adamo, C. R., \& Sahin, A. (2014). Soy foods and supplementation: a review of commonly perceived health benefits and risks. Alternative Therapies in Health and Medicine, 20(Suppl. 1), 39-51. PMid:24473985.

Dinsdale, E. C., \& Ward, W. E. (2010). Early exposure to soy isoflavones and effects on reproductive health: a review of human and animal studies. Nutrients, 2(11), 1156-1187. PMid:22254003. http://dx.doi.org/10.3390/nu2111156

Doerge, D. R. (2011). Bioavailability of soy isoflavones through placental/lactational transfer and soy food. Toxicology and Applied Pharmacology, 254(2), 145-147. PMid:21034763. http://dx.doi.org/10.1016/j.taap.2010.10.018

Dong, J. Y., \& Qin, L. Q. (2011). Soy isoflavones consumption and risk of breast cancer incidence or recurrence: a metaanalysis of prospective studies. Breast Cancer Research and Treatment, 125(2), 315-323. PMid:21113655.

http://dx.doi.org/10.1007/s10549-010-1270-8

Dong, J. Y., Wang, P., He, K., \& Qin, L. Q. (2011). Effect of soy isoflavones on circulating C-reactive protein in postmenopausal women: meta-analysis of randomized controlled trials. Menopause (New York, N.Y.), 18(11), 1256-1262. PMid:21712733. http://dx.doi.org/10.1097/gme.0b013e31821bfa24 
Donovan, S. M., Andres, A., Mathai, R. A., Kuhlenschmidt, T. B., \& Kuhlenschmidt, M. S. (2009). Soy formula and isoflavones and the developing intestine. Nutrition Reviews, 67(Suppl. 2), S192-S200. PMid:19906223. http://dx.doi.org/10.1111/j.17534887.2009.00240.x

Douglas, C. C., Johnson, S. A., \& Arjmandi, B. H. (2013). Soy and its isoflavones: the truth behind the science in breast cancer. Anti-cancer Agents in Medicinal Chemistry, 13(8), 1178-1187. PMid:23919747. http://dx.doi.org/10.2174/18715206113139990320

Eakin, A., Kelsberg, G., \& Safranek, S. (2015). Clinical Inquiry: does high dietary soy intake affect a woman's risk of primary or recurrent breast cancer? The Journal of Family Practice, 64(10), 660-662. PMid:26551478.

Franke, A. A., Lai, J. F., \& Halm, B. M. (2014). Absorption, distribution, metabolism, and excretion of isoflavonoids after soy intake. Archives of Biochemistry and Biophysics, 559, 24-28. PMid:24946051. http://dx.doi.org/10.1016/j.abb.2014.06.007

Friedman, M., \& Brandon, D. L. (2001). Nutritional and health benefits of soy proteins. Journal of Agricultural and Food Chemistry, 49(3), 1069-1086. PMid:11312815. http://dx.doi.org/10.1021/jf0009246

Gil-Izquierdo, A., Penalvo, J. L., Gil, J. I., Medina, S., Horcajada, M. N., Lafay, S., Silberberg, M., Llorach, R., Zafrilla, P., Garcia-Mora, P., \& Ferreres, F. (2012). Soy isoflavones and cardiovascular disease epidemiological, clinical and -omics perspectives. Current Pharmaceutical Biotechnology, 13(5), 624-631. PMid:22122477. http://dx.doi.org/10.2174/138920112799857585

Hamilton-Reeves, J. M., Vazquez, G., Duval, S. J., Phipps, W. R., Kurzer, M. S., \& Messina, M. J. (2010). Clinical studies show no effects of soy protein or isoflavones on reproductive hormones in men: results of a meta-analysis. Fertility and Sterility, 94(3), 997-1007. PMid:19524224. http://dx.doi.org/10.1016/j.fertnstert.2009.04.038

Health Canada. (2015). Summary of Health Canada's assessment of a health claim about soy protein and cholesterol lowering. Canada: Health Canada. Retrieved in 2019, May 27, from https://www.canada.ca/en/health-canada/services/food-nutrition/foodlabelling/health-claims/assessments/summary-assessment-health-claim-about-protein-cholesterol-lowering.html

Helferich, W. G., Andrade, J. E., \& Hoagland, M. S. (2008). Phytoestrogens and breast cancer: a complex story. Inflammopharmacology, 16(5), 219-226. PMid:18815740. http://dx.doi.org/10.1007/s10787-008-8020-0

Hilakivi-Clarke, L., Andrade, J. E., \& Helferich, W. (2010). Is soy consumption good or bad for the breast? The Journal of Nutrition, 140(12), 2326s-2334s. PMid:20980638. http://dx.doi.org/10.3945/jn.110.124230

Hillman, G. G., \& Singh-Gupta, V. (2011). Soy isoflavones sensitize cancer cells to radiotherapy. Free Radical Biology \& Medicine, 51(2), 289-298. PMid:21605661. http://dx.doi.org/10.1016/j.freeradbiomed.2011.04.039

Huang, H., Krishnan, H. B., Pham, Q., Yu, L. L., \& Wang, T. T. (2016). Soy and gut microbiota: interaction and implication for human health. Journal of Agricultural and Food Chemistry, 64(46), 8695-8709. PMid:27798832. http://dx.doi.org/10.1021/acs.jafc.6b03725

Huber, J., \& Genazzani, A. R. (2016). The importance of isoflavones for women's Health Frontiers in Gynecological endocrinology (pp. 185-194). USA: Springer. http://dx.doi.org/10.1007/978-3-319-23865-4_22.

Hughes, G. J., Ryan, D. J., Mukherjea, R., \& Schasteen, C. S. (2011). Protein digestibility-corrected amino acid scores (PDCAAS) for soy protein isolates and concentrate: criteria for evaluation. Journal of Agricultural and Food Chemistry, 59(23), 12707-12712. PMid:22017752. http://dx.doi.org/10.1021/jf203220v

Imai, S. (2015). Soybean and processed soy foods ingredients, and their role in cardiometabolic risk prevention. Recent Patents on Food, Nutrition \& Agriculture, 7(2), 75-82. PMid:26118770. http://dx.doi.org/10.2174/2212798407666150629123839

Jian, L. (2009). Soy, isoflavones, and prostate cancer. Molecular Nutrition \& Food Research, 53(2), 217-226. PMid:18985655. http://dx.doi.org/10.1002/mnfr.200800167

Johnson, K., Loomis, G., Flake, D., \& Harrison, S. (2008). Effects of soy protein-based formula in full-term infants. American Family Physician, 77(1), 87-88. PMid:18236828.

Katz, Y., Gutierrez-Castrellon, P., Gonzalez, M. G., Rivas, R., Lee, B. W., \& Alarcon, P. (2014). A comprehensive review of sensitization and allergy to soy-based products. Clinical Reviews in Allergy \& Immunology, 46(3), 272-281. PMid:24425446. http://dx.doi.org/10.1007/s12016-013-8404-9

Kemp, A. (2006). Hypoallergenic formula prescribing practices in Australia. Journal of Paediatrics and Child Health, 42(4), 191195. PMid:16630320. http://dx.doi.org/10.1111/j.1440-1754.2006.00828.x

Kim, J. (2008). Protective effects of Asian dietary items on cancers - soy and ginseng. Asian Pacific Journal of Cancer Prevention, 9(4), 543-548. PMid:19256735.

Kubota, M., \& Shimizu, H. (2009). Nutrition and bone health. Soybean and soy foods, and bone health. Clinical Calcium, 19(10), 1514-1519. PMID: 19794262.

Kurzer, M. S. (2008). Soy consumption for reduction of menopausal symptoms. Inflammopharmacology, 16(5), 227-229. PMid:18815739. http://dx.doi.org/10.1007/s10787-008-8021-z

Levis, S., \& Griebeler, M. L. (2010). The role of soy foods in the treatment of menopausal symptoms. The Journal of Nutrition, 140(12), 2318s-2321s. PMid:21047930. http://dx.doi.org/10.3945/jn.110.124388

Li, W., Ruan, W., Peng, Y., \& Wang, D. (2018). Soy and the risk of type 2 diabetes mellitus: A systematic review and metaanalysis of observational studies. Diabetes Research and Clinical Practice, 137, 190-199. PMid:29407270. http://dx.doi.org/10.1016/j.diabres.2018.01.010

Liu, X. X., Li, S. H., Chen, J. Z., Sun, K., Wang, X. J., Wang, X. G., \& Hui, R. T. (2012). Effect of soy isoflavones on blood pressure: a meta-analysis of randomized controlled trials. Nutrition, Metabolism, and Cardiovascular Diseases, 22(6), 463-470. PMid:21310599. http://dx.doi.org/10.1016/j.numecd.2010.09.006 
Ma, L., Liu, G., Ding, M., Zong, G., Hu, F. B., Willett, W. C., Rimm, E. B., Manson, J. E., \& Sun, Q. (2020). Isoflavone intake and the risk of coronary heart disease in US men and women: results from 3 prospective cohort studies. Circulation, 141(14), 11271137. PMid:32200662. http://dx.doi.org/10.1161/CIRCULATIONAHA.119.041306

Magee, P. J., \& Rowland, I. (2012). Soy products in the management of breast cancer. Current Opinion in Clinical Nutrition and Metabolic Care, 15(6), 586-591. PMid:23075937. http://dx.doi.org/10.1097/MCO.0b013e328359156f

Mahmoud, A. M., Yang, W., \& Bosland, M. C. (2014). Soy isoflavones and prostate cancer: a review of molecular mechanisms. The Journal of Steroid Biochemistry and Molecular Biology, 140, 116-132. PMid:24373791. http://dx.doi.org/10.1016/j.jsbmb.2013.12.010

McCarver, G., Bhatia, J., Chambers, C., Clarke, R., Etzel, R., Foster, W., Hoyer, P., Leeder, J. S., Peters, J. M., Rissman, E., Rybak, M., Sherman, C., Toppari, J., \& Turner, K. (2011). NTP-CERHR expert panel report on the developmental toxicity of soy infant formula. Birth Defects Research. Part B, Developmental and Reproductive Toxicology, 92(5), 421-468. PMid:21948615. http://dx.doi.org/10.1002/bdrb.20314

Medic, J., Atkinson, C., \& Hurburgh Junior, C. R. (2014). Current knowledge in soybean composition. Journal of the American Oil Chemists' Society, 91(3), 363-384. http://dx.doi.org/10.1007/s11746-013-2407-9

Mendes, K. D. S., Silveira, R. C. C. P., \& Galvão, C. M. (2008). Revisão integrativa: método de pesquisa para a incorporação de evidências na saúde e na enfermagem. Texto \& Contexto Enfermagem, 17(4), 758-764. http://dx.doi.org/10.1590/S010407072008000400018

Messina, M. (2010). A brief historical overview of the past two decades of soy and isoflavone research. The Journal of Nutrition, 140(7), 1350s-1354s. PMid:20484551. http://dx.doi.org/10.3945/jn.109.118315

Messina, M. (2016a). Impact of soy foods on the development of breast cancer and the prognosis of breast cancer patients. Forschende Komplementarmedizin, 23(2), 75-80. PMid:27161216. http://dx.doi.org/10.1159/000444735.

Messina, M. (2016b). Soy and health update: evaluation of the clinical and epidemiologic literature. Nutrients, 8(12), 754. PMid:27886135. http://dx.doi.org/10.3390/nu8120754

Messina, M. J., \& Wood, C. E. (2008). Soy isoflavones, estrogen therapy, and breast cancer risk: analysis and commentary. Nutrition Journal, 7(1), 17. PMid:18522734. http://dx.doi.org/10.1186/1475-2891-7-17

Messina, M., \& Messina, V. (2010). The role of soy in vegetarian diets. Nutrients, 2(8), 855-888. PMid:22254060. http://dx.doi.org/10.3390/nu2080855

Messina, M., Rogero, M. M., Fisberg, M., \& Waitzberg, D. (2017). Health impact of childhood and adolescent soy consumption. Nutrition Reviews, 75(7), 500-515. PMid:28838083. http://dx.doi.org/10.1093/nutrit/nux016

Mezzomo, T. R., \& Nadal, J. (2016). Efeito dos nutrientes e substâncias alimentares na função tireoidiana e no hipotireoidismo. DEMETRA: alimentação. Nutrição \& Saúde, 11(2), 427-443.

Moe, S. M., Zidehsarai, M. P., Chambers, M. A., Jackman, L. A., Radcliffe, J. S., Trevino, L. L., Donahue, S. E., \& Asplin, J. R. (2011). Vegetarian compared with meat dietary protein source and phosphorus homeostasis in chronic kidney disease. Clinical Journal of the American Society of Nephrology; CJASN, 6(2), 257-264. PMid:21183586. http://dx.doi.org/10.2215/CJN.05040610

Mourouti, N., \& Panagiotakos, D. B. (2013). Soy food consumption and breast cancer. Maturitas, 76(2), 118-122. PMid:23916376. http://dx.doi.org/10.1016/j.maturitas.2013.07.006

Myung, S. K., Ju, W., Choi, H. J., \& Kim, S. C., \& Korean Meta-Analysis (KORMA) Study Group. (2009). Soy intake and risk of endocrine-related gynaecological cancer: a meta-analysis. BJOG, 116(13), 1697-1705. PMid:19775307. http://dx.doi.org/10.1111/j.1471-0528.2009.02322.x

Nagata, C. (2010). Factors to consider in the association between soy isoflavone intake and breast cancer risk. Journal of Epidemiology, 20(2), 83-89. PMid:20173308. http://dx.doi.org/10.2188/jea.JE20090181

Nagata, C., Mizoue, T., Tanaka, K., Tsuji, I., Tamakoshi, A., Matsuo, K., Wakai, K., Inoue, M., Tsugane, S., Sasazuki, S., Sasazuki, S., Tsugane, S., Inoue, M., Iwasaki, M., Otani, T., Sawada, N., Shimazu, T., Yamaji, T., Tsuji, I., Tsubono, Y., Nishino, Y., Tamakoshi, A., Matsuo, K., Ito, H., Wakai, K., Nagata, C., Mizoue, T., \& Tanaka, K., \& Research Group for the Development and Evaluation of Cancer Prevention Strategies in Japan. (2014). Soy intake and breast cancer risk: an evaluation based on a systematic review of epidemiologic evidence among the Japanese population. Japanese Journal of Clinical Oncology, 44(3), 282-295. PMid:24453272. http://dx.doi.org/10.1093/jjco/hyt203

Noori, N., Sims, J. J., Kopple, J. D., Shah, A., Colman, S., Shinaberger, C. S., Bross, R., Mehrotra, R., Kovesdy, C. P., \& Kalantar-Zadeh, K. (2010). Organic and inorganic dietary phosphorus and its management in chronic kidney disease. Iranian Journal of Kidney Diseases, 4(2), 89-100. PMid:20404416.

Ørgaard, A., \& Jensen, L. (2008). The effects of soy isoflavones on obesity. Experimental Biology and Medicine (Maywood, N.J.), 233(9), 1066-1080. PMid:18535167. http://dx.doi.org/10.3181/0712-MR-347

Pires, C. V., Oliveira, M. G. A., Rosa, J. C., \& Costa, N. M. B. (2006). Qualidade nutricional e escore químico de aminoácidos de diferentes fontes protéicas. Food Science and Technology (Campinas), 26(1), 179-187. http://dx.doi.org/10.1590/S010120612006000100029

Poulsen, R. C., \& Kruger, M. C. (2008). Soy phytoestrogens: impact on postmenopausal bone loss and mechanisms of action. Nutrition Reviews, 66(7), 359-374. PMid:18667012. http://dx.doi.org/10.1111/j.1753-4887.2008.00046.x

Ramdath, D. D., Padhi, E. M., Sarfaraz, S., Renwick, S., \& Duncan, A. M. (2017). Beyond the cholesterol-lowering effect of soy protein: a review of the effects of dietary soy and its constituents on risk factors for cardiovascular disease. Nutrients, 9(4), 324. PMid:28338639. http://dx.doi.org/10.3390/nu9040324 
Ricci, E., Cipriani, S., Chiaffarino, F., Malvezzi, M., \& Parazzini, F. (2010). Soy isoflavones and bone mineral density in perimenopausal and postmenopausal Western women: a systematic review and meta-analysis of randomized controlled trials. Journal of Women's Health, 19(9), 1609-1617. PMid:20673147. http://dx.doi.org/10.1089/jwh.2010.2021

Rizzo, G., \& Baroni, L. (2018). Soy, soy foods and their role in vegetarian diets. Nutrients, 10(1), 43. PMid:29304010. http://dx.doi.org/10.3390/nu10010043

Rossouw, J. E., Anderson, G. L., Prentice, R. L., LaCroix, A. Z., Kooperberg, C., Stefanick, M. L., Jackson, R. D., Beresford, S. A., Howard, B. V., Johnson, K. C., Kotchen, J. M., \& Ockene, J., \& Writing Group for the Women's Health Initiative Investigators. (2002). Risks and benefits of estrogen plus progestin in healthy postmenopausal women: principal results From the Women's Health Initiative randomized controlled trial. Journal of the American Medical Association, 288(3), 321-333. PMid:12117397. http://dx.doi.org/10.1001/jama.288.3.321

Sakai, T., \& Kogiso, M. (2008). Soy isoflavones and immunity. The Journal of Medical Investigation, 55(3-4), 167-173. PMid:18797128. http://dx.doi.org/10.2152/jmi.55.167

Silva, M. R., \& Silva, M. A. A. P. (2000). Fatores antinutricionais: inibidores de proteases e lectinas. Revista de Nutrição, 13(1), 3-9. http://dx.doi.org/10.1590/S1415-52732000000100001

Solé, D., Silva, L. R., Cocco, R. R., Ferreira, C. T., Sarni, R. O., Oliveira, L. C., Pastorino, A. C., Weffort, V., Morais, M. B., Barreto, B. P., Oliveira, J. C., Castro, A. P. M., Franco, J. M., Chong, H. J., Rosário, N. A., Alonso, M. L. O., Sarinho, E. C., Yang, A., Maranhão, H., Toporovski, M. S., Epifanio, M., Wandalsen, N. F., \& Rubini, N. M. (2018). Consenso Brasileiro sobre Alergia Alimentar: 2018 - Parte 2 - Diagnóstico, tratamento e prevenção. Documento conjunto elaborado pela Sociedade Brasileira de Pediatria e Associação Brasileira de Alergia e Imunologia. Arquivos de Asma, Alergia e Imunologia, 2(1), http://dx.doi.org/10.5935/2526-5393.20180005

Sugiyama, Y., Masumori, N., Fukuta, F., Yoneta, A., Hida, T., Yamashita, T., Minatoya, M., Nagata, Y., Mori, M., Tsuji, H., Akaza, H., \& Tsukamoto, T. (2013). Influence of isoflavone intake and equol-producing intestinal flora on prostate cancer risk. Asian Pacific Journal of Cancer Prevention, 14(1), 1-4. PMid:23534704. http://dx.doi.org/10.7314/APJCP.2013.14.1.1

Taku, K., Melby, M. K., Kurzer, M. S., Mizuno, S., Watanabe, S., \& Ishimi, Y. (2010). Effects of soy isoflavone supplements on bone turnover markers in menopausal women: systematic review and meta-analysis of randomized controlled trials. Bone, 47(2), 413-423. PMid:20452475. http://dx.doi.org/10.1016/j.bone.2010.05.001

Talaei, M., Koh, W.-P., van Dam, R. M., Yuan, J.-M., \& Pan, A. (2014). Dietary soy intake is not associated with risk of cardiovascular disease mortality in Singapore Chinese Adults. The Journal of Nutrition, 144(6), 921-928. PMid:24699802. http://dx.doi.org/10.3945/jn.114.190454

Tansaz, S., \& Boccaccini, A. R. (2016). Biomedical applications of soy protein: a brief overview. Journal of Biomedical Materials Research. Part A, 104(2), 553-569. PMid:26402327. http://dx.doi.org/10.1002/jbm.a.35569

Tezuka, H., \& Imai, S. (2015). Immunomodulatory effects of soybeans and processed soy food compounds. Recent Patents on Food, Nutrition \& Agriculture, 7(2), 92-99. PMid:26118769. http://dx.doi.org/10.2174/2212798407666150629123957

Tomayko, E. J., Kistler, B. M., Fitschen, P. J., \& Wilund, K. R. (2015). Intradialytic protein supplementation reduces inflammation and improves physical function in maintenance hemodialysis patients. Journal of Renal Nutrition, 25(3), 276-283. PMid:25455421. http://dx.doi.org/10.1053/j.jrn.2014.10.005

Tse, G., \& Eslick, G. D. (2016). Soy and isoflavone consumption and risk of gastrointestinal cancer: a systematic review and meta-analysis. European Journal of Nutrition, 55(1), 63-73. PMid:25547973. http://dx.doi.org/10.1007/s00394-014-0824-7

Valladares, L., Garrido, A., \& Sierralta, W. (2012). Soy isoflavones and human health: breast cancer and puberty timing. Revista Medica de Chile, 140(4), 512-516. PMid:22854699. http://dx.doi.org/10.4067/S0034-98872012000400014

van Die, M. D., Bone, K. M., Williams, S. G., \& Pirotta, M. V. (2014). Soy and soy isoflavones in prostate cancer: a systematic review and meta-analysis of randomized controlled trials. BJU International, 113(5b), E119-E130. PMid:24053483. http://dx.doi.org/10.1111/bju.12435

Vandenplas, Y., Castrellon, P. G., Rivas, R., Gutierrez, C. J., Garcia, L. D., Jimenez, J. E., Anzo, A., Hegar, B., \& Alarcon, P. (2014). Safety of soya-based infant formulas in children. British Journal of Nutrition, 111(8), 1340-1360. PMid:24507712. http://dx.doi.org/10.1017/S0007114513003942

Vandenplas, Y., De Greef, E., Devreker, T., \& Hauser, B. (2011). Soy infant formula: is it that bad? Acta Paediatrica (Oslo, Norway : 1992), 100(2), 162-166. PMid:20860705. http://dx.doi.org/10.1111/j.1651-2227.2010.02021.x

Varinska, L., Gal, P., Mojzisova, G., Mirossay, L., \& Mojzis, J. (2015). Soy and breast cancer: focus on angiogenesis. International Journal of Molecular Sciences, 16(5), 11728-11749. PMid:26006245. http://dx.doi.org/10.3390/ijms160511728

Wei, P., Liu, M., Chen, Y., \& Chen, D. C. (2012). Systematic review of soy isoflavone supplements on osteoporosis in women. Asian Pacific Journal of Tropical Medicine, 5(3), 243-248. PMid:22305793. http://dx.doi.org/10.1016/S1995-7645(12)60033-9

Wu, A. H., Yu, M. C., Tseng, C. C., \& Pike, M. C. (2008). Epidemiology of soy exposures and breast cancer risk. British Journal of Cancer, 98(1), 9-14. PMid:18182974. http://dx.doi.org/10.1038/sj.bjc.6604145

Xiao, C. W. (2008). Health effects of soy protein and isoflavones in humans. The Journal of Nutrition, 138(6), 1244s-1249s. PMid:18492864. http://dx.doi.org/10.1093/jn/138.6.1244S

Yan, Z., Zhang, X., Li, C., Jiao, S., \& Dong, W. (2017). Association between consumption of soy and risk of cardiovascular disease: A meta-analysis of observational studies. European Journal of Preventive Cardiology, 24(7), 735-747. PMid:28067550. http://dx.doi.org/10.1177/2047487316686441

Yu, Y., Jing, X., Li, H., Zhao, X., \& Wang, D. (2016). Soy isoflavone consumption and colorectal cancer risk: a systematic review and meta-analysis. Scientific Reports, 6(1), 25939. PMid:27170217. http://dx.doi.org/10.1038/srep25939 
Zeiger, R. S., Sampson, H. A., Bock, S. A., Burks Junior, A. W., Harden, K., Noone, S., Martin, D., Leung, S., \& Wilson, G. (1999). Soy allergy in infants and children with IgE-associated cow's milk allergy. The Journal of Pediatrics, 134(5), 614-622. PMid:10228298. http://dx.doi.org/10.1016/S0022-3476(99)70249-0

Zhang, G. Q., Chen, J. L., Liu, Q., Zhang, Y., Zeng, H., \& Zhao, Y. (2015). Soy intake is associated with lower endometrial cancer risk: a systematic review and meta-analysis of observational studies. Medicine, 94(50), e2281. PMid:26683956. http://dx.doi.org/10.1097/MD.0000000000002281

Zhang, Y. B., Chen, W. H., Guo, J. J., Fu, Z. H., Yi, C., Zhang, M., \& Na, X. L. (2013). Soy isoflavone supplementation could reduce body weight and improve glucose metabolism in non-Asian postmenopausal women--a meta-analysis. Nutrition (Burbank, Los Angeles County, Calif.), 29(1), 8-14. PMid:22858192. http://dx.doi.org/10.1016/j.nut.2012.03.019

Zhang, Y., Chen, W. F., Lai, W. P., \& Wong, M. S. (2008). Soy isoflavones and their bone protective effects. Inflammopharmacology, 16(5), 213-215. PMid:18815742. http://dx.doi.org/10.1007/s10787-008-8018-7 